Abstracta Iranica Abstanica

Revue bibliographique pour le domaine irano-aryen

Volume 29 | 2008

Comptes rendus des publications de 2006

\title{
Confronting Iran: the failure of American foreign policy and the roots of mistrust. Hurst, 2006, 176 p.
}

\section{Anicée Van Engeland}

\section{(2) OpenEdition}

10 Journals

Édition électronique

URL : http://journals.openedition.org/abstractairanica/32102

DOI : 10.4000/abstractairanica.32102

ISSN : 1961-960X

\section{Éditeur :}

CNRS (UMR 7528 Mondes iraniens et indiens), Éditions de l'IFRI

\section{Édition imprimée}

Date de publication : 15 mai 2008

ISSN : 0240-8910

\section{Référence électronique}

Anicée Van Engeland, «Confronting Iran: the failure of American foreign policy and the roots of mistrust. Hurst, 2006, 176 p. », Abstracta Iranica [En ligne], Volume 29 | 2008, document 360, mis en ligne le 15 septembre 2008, consulté le 26 septembre 2020. URL : http://journals.openedition.org/ abstractairanica/32102 ; DOI : https://doi.org/10.4000/abstractairanica.32102

Ce document a été généré automatiquement le 26 septembre 2020.

Tous droits réservés 
Confronting Iran: the failure of American foreign policy and the roots of mistrust. Hurst, 2006, 176 p.

\author{
Anicée Van Engeland
}

1 Dans cet ouvrage, Ansari analyse la crise entre les États-Unis et l'Iran depuis 1979. Il revoit tous les événements antérieurs à cette époque qui ont mené à la rupture de 1979 ; il étudie aussi l'impact des événements du 11 septembre 2001 sur la relation entre les deux pays, intègrant dans sa réflexion le rôle de l'Union Européenne. L'A. estime que la position de l'UE à l'égard de l'Iran a beaucoup influencé les États-Unis. La conclusion se penche sur l'Iran d'Ahmadinejad et ses relations avec ces deux grandes puissances.

INDEX

Thèmes : 13.1. Iran

\title{
AUTEURS
}

\section{ANICÉE VAN ENGELAND}

European University Institute - Florence 